\title{
Nordic Regimen
}

National Cancer Institute

\section{Source}

National Cancer Institute. Nordic Regimen. NCI Thesaurus. Code C140110.

A regimen consisting of cycles of rituximab with cyclophosphamide, doxorubicin, vincristine and prednisone (Maxi-CHOP), alternating with rituximab with high-dose (HD) cytarabine that can be used in the treatment of mantle cell lymphoma (MCL). 